upon that fuller knowledge of fact and of the historic sequence of cultures in the respective areas, and on the practise of the general principles of evidence some of which I have here attempted to set forth and illustrate.

Anthropologists are at present, as was recently pointed out by Dr. Rivers in his address as vice-president of the section in the British Association, in the unfortunate condition of not agreeing on fundamental questions of method. We have, it is hoped, left behind us the period of vague and futile theorizing without facts or with too few facts, but there are still many who believe that evolution is the master-key which will unlock all doors, and that by the amassing of more or less heterogeneous and unrelated facts from all over the world a continuous development through definite stages of culture may everywhere be shown. The partizans of independent development based on the theory of the psychological unity of the human mind, are set over against those who believe in the complexity of cultures, and the possibility that by analysis and comparison their historic relationships may be determined, and who would explain similarities in culture between widely separated peoples on this basis or on that of convergent evolution. Here in America we have come to feel, I think, more perhaps than elsewhere, that no one of these theories is a panacea. As a result of the experience of the last decade or so in attempting to outline and define the several culture areas in this continent, we are beginning to realize that these several points of view may all and at the same time be true, and to admit that in a given culture, whereas some elements are undoubtedly the outcome of contact or transmission, others may be the result of evolutionary development, and dependent on the general uni- formity of reaction to similar stimuli among mankind as a whole; and we are prepared, I trust, to agree that if fact and theory do not conform, it is the latter for which the Procrustean bed should be reserved.

It is in this spirit, then, of insistence on abundant fact and its careful interpretation, without prejudice and unencumbered with rigid theories which will admit of no compromise, that I believe we should approach the question of the independence of American culture; a question which has its greatest interest quite naturally for us in America, but which for anthropology as a whole is also of great and far-reaching importance.

Roland B. Dixon

\section{THE PERCENTACE OF WOMEN TEACHERS IN STATE COLLEGES AND UNIVERSITIES ${ }^{1}$}

THE average per cent. of women teachers for all the state colleges and universities is $9+$. The average for the schools west of the Mississippi is $13+$ per cent., while for the schools east of the Mississippi it is $6+$ per cent.

Eleven schools, ${ }^{2}$ which were selected at random, have 149 women teachers. Of these 149, $10+$ per cent. are full professors, $5+$ per cent. are associate professors, $10+$ per cent. are assistant professors and $73+$ per cent. instructors.

As to the subjects these 149 women teach, the distribution is: professors, home econom-

1 These figures base upon "Statisties of State Universities and other Institutions of Higher Education Partially Supported by the State,' for the year ended June, 1910 (Washington, Government Printing Office), and catalogues of eleven institutions for the year 1910 .

2 The eleven schools are: University of Arizona, Iowa State College, Miami University, University of Montana, University of New Mexico, North Dakota Agricultural College, Ohio University, University of Oklahoma, University of South Dakota, University of Utah, University of Wyoming. 


\begin{tabular}{|c|c|c|c|}
\hline \multirow{2}{*}{ Name of Institution: } & \multicolumn{2}{|c|}{$\begin{array}{l}\text { Professors and } \\
\text { Instructors }\end{array}$} & \multirow{2}{*}{ 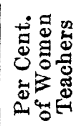 } \\
\hline & $\begin{array}{l}\text { Wo- } \\
\text { men }\end{array}$ & Total & \\
\hline Alak & 0 & 65 & \\
\hline of $\mathrm{Al}$ & 0 & 54 & \\
\hline$y$ of $\mathrm{Ar}$ & 11 & 42 & $26+$ \\
\hline Un & 19 & 133 & $14+$ \\
\hline $\mathrm{Ur}$ & 6 & 297 & $02+$ \\
\hline Univ & 14 & 141 & $09-$ \\
\hline State Agricultural Colle & 11 & 67 & $16-$ \\
\hline Colorado School of Mir & 0 & 20 & 0 \\
\hline Con & 5 & 24 & 20 \\
\hline De & 0 & & 0 \\
\hline Un & 0 & & 0 \\
\hline Flo & 14 & 25 & 56 \\
\hline Uni & 0 & 48 & 0 \\
\hline Georgia School of 'I & 0 & 48 & 0 \\
\hline \multicolumn{4}{|l|}{ North Georgia Agricultural Col- } \\
\hline 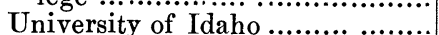 & $\begin{array}{l}2 \\
0\end{array}$ & 15 & $13+$ \\
\hline Un & 9 & & $17+$ \\
\hline Indi & 53 & 56 & $09+$ \\
\hline Purdue University (Ind.). & $\begin{array}{r}10 \\
9\end{array}$ & 1 & 05 \\
\hline \multirow{2}{*}{\multicolumn{4}{|c|}{$\begin{array}{l}\text { Iowa State College of Agriculture } \\
\text { and Mechanic Arts................. }\end{array}$}} \\
\hline & & & 23 \\
\hline State University of Iowa............ & 14 & 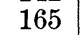 & $08+$ \\
\hline & 28 & 187 & $14-$ \\
\hline $\mathrm{Ka}$ & 44 & 157 & \\
\hline State University ( $\mathrm{K}$ ) & 4 & 67 & 05 \\
\hline \multirow{2}{*}{\multicolumn{4}{|c|}{$\begin{array}{l}\text { Louisiana State University and } \\
\text { Agricultural and Mechanical } \\
\text { College }\end{array}$}} \\
\hline & & & \\
\hline University of Maine....................... & 3 & 59 & $05+$ \\
\hline Mar & $\begin{array}{l}2 \\
0\end{array}$ & 77 & $02-$ \\
\hline Massachusetts AgriculturalCollege & $\begin{array}{l}0 \\
0\end{array}$ & 29 & 0 \\
\hline \multirow{2}{*}{\multicolumn{4}{|c|}{ 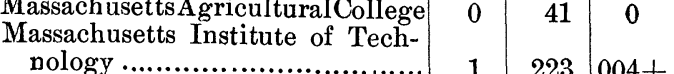 }} \\
\hline & 1 & 223 & 004 \\
\hline Unive & 4 & 317 & 01 \\
\hline \multirow{2}{*}{\multicolumn{4}{|c|}{$\begin{array}{l}\text { Michigan State Agricultural Col- } \\
\text { lege ...................... }\end{array}$}} \\
\hline & & 104 & 20 \\
\hline Micl & 0 & 30 & 0 \\
\hline University of $M$ & 9 & 193 & 04 \\
\hline \multicolumn{4}{|l|}{ 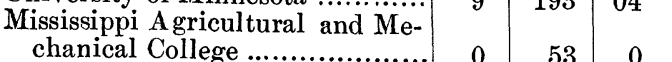 } \\
\hline $\begin{array}{l}\text { chanical College ................ } \\
\text { University of Mississippi }{ }^{3}\end{array}$ & 0 & 5 & 0 \\
\hline Univ & 0 & 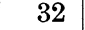 & 0 \\
\hline \multirow{2}{*}{\multicolumn{4}{|c|}{$\begin{array}{l}\text { University of Missouri................ } \\
\text { Montana College of Agriculture } \\
\text { and Mechanic Arts................ }\end{array}$}} \\
\hline & 10 & 45 & 22 - $-2-1-$ \\
\hline a State School of Mines... & 0 & $x$ & 0 \\
\hline ty of $N$ & 5 & 24 & \\
\hline of & 42 & 261 & \\
\hline University of Nevada.. & 9 & 40 & 22 \\
\hline \multirow{2}{*}{\multicolumn{4}{|c|}{$\begin{array}{l}\text { New Hampshire College of Agri- } \\
\text { culture and Mechanic }\end{array}$}} \\
\hline & 0 & 35 & 0 \\
\hline Rutgers College (N. J.) .............. & 7 & 56 & 12 \\
\hline \multicolumn{4}{|l|}{$\begin{array}{l}\text { New Mexico College of Agricul- } \\
\text { ture and Mechanic }\end{array}$} \\
\hline University of New Mexico & 5 & 1 & \\
\hline New & C & & \\
\hline Corn & 16 & 636 & 02 \\
\hline University of North Carolina & & 99 & \\
\hline \multirow{2}{*}{$\begin{array}{l}\text { North Carolina College of Agri- } \\
\text { culture and Mechanic Arts ..... }\end{array}$} & & & \\
\hline & & 4 & \\
\hline
\end{tabular}

${ }^{3}$ From 1909 report.

\begin{tabular}{|c|c|c|c|}
\hline \multirow{2}{*}{ Name of Institution } & \multicolumn{2}{|c|}{$\begin{array}{l}\text { Professors and } \\
\text { Instructors }\end{array}$} & \multirow{2}{*}{ 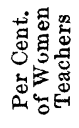 } \\
\hline & $\begin{array}{l}\text { Wo- } \\
\text { men }\end{array}$ & Total & \\
\hline 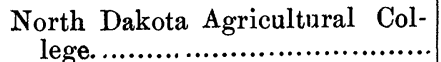 & \multirow{2}{*}{10} & \multirow[t]{2}{*}{62} & \multirow{2}{*}{$16+$} \\
\hline State University and School of & & & \\
\hline Mines (N. Dak.) ..................... & 12 & 77 & $15+$ \\
\hline Ohio University ................. & 24 & 58 & $41+$ \\
\hline Ohio State University......... & 14 & 214 & $06+$ \\
\hline Miami University (Ohio) ... & 8 & 53 & $15+$ \\
\hline University of Oklahoma ....... & 11 & 63 & $17+$ \\
\hline $\begin{array}{l}\text { Oklahoma Agricultural and Me- } \\
\text { chanical College ......................... }\end{array}$ & 12 & 63 & $17+-$ \\
\hline Oregon State Agricultural Col- & & & \\
\hline 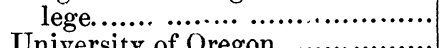 & 19 & 89 & $\begin{array}{l}21+ \\
07+\end{array}$ \\
\hline $\begin{array}{l}\text { University of Oregon ............ } \\
\text { Pennsylvania State College .. }\end{array}$ & $\begin{array}{r}8 \\
10\end{array}$ & $\begin{array}{l}102 \\
149\end{array}$ & $\begin{array}{l}07+ \\
06+\end{array}$ \\
\hline Rhode Island State College.......... & 5 & 27 & $14+$ \\
\hline South Carolina Military Academy & 0 & 13 & 0 \\
\hline 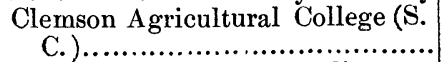 & 0 & 48 & 0 \\
\hline University of South Carolina. & 3 & 32 & $09+$ \\
\hline South Dakota Agricultural College & 7 & 52 & $13+$ \\
\hline South Dakota State School of Mines & 0 & 16 & 0 \\
\hline University of South Dakota......... & 12 & 46 & $26+$ \\
\hline University of Tennessee............. & 9 & 143 & $06+$ \\
\hline 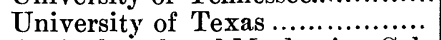 & 6 & 103 & $05+$ \\
\hline Agricultural and Mechanica Col- & & & \\
\hline lege of Texas. . & 0 & 52 & 0 \\
\hline Agricultural College of Utah & 11 & 58 & $18+$ \\
\hline University of Utah............ & 16 & 74 & $21+$ \\
\hline $\begin{array}{l}\text { University of Vermont and Agri- } \\
\text { cultural College......................... }\end{array}$ & 1 & 89 & $01+$ \\
\hline Virginia Polytechnic Institute..... & 0 & 64 & 0 \\
\hline University of Virginia ............. & 0 & 76 & 0 \\
\hline Virginia Military Institute.. & 0 & 22 & 0 \\
\hline College of William and Mary & & & \\
\hline State Colle & $\begin{array}{r}0 \\
10\end{array}$ & $\begin{array}{l}20 \\
77\end{array}$ & 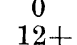 \\
\hline University of Washington.. & 4 & 103 & $03+$ \\
\hline West Virginia University ... & 15 & 91 & $16+$ \\
\hline University of Wisconsin .... & 38 & 459 & $08+$ \\
\hline University of Wyoming.... & 14 & 43 & $22+$ \\
\hline
\end{tabular}

ics, 3; English, 2; modern language, 2; history and Spanish, 1; philosophy, 1; political science, 1; school training, 2; fine arts, 1; physical education and elocution, 1 , and clinical medicine, 1.

Associate professors: English, 2; chemistry, 2 ; domestic science, 1 ; mathematics (and dean), 1; commercial, 1; library science, 1.

Assistant professors: English, 7; domestic economy, 3; Latin and Greek, 2; philosophy, 1 ; mathematics, 1 ; public speaking, 1 ; history, 1.

Instructors: music, 20; modern language, 14; English, 13; natural science, 8; school training, 7 ; history, 8 ; physical education, 6 ; 
art, 6 ; commercial branches, 5 ; mathematics, 4; domestic science, 5; public speaking, 3; ancient languages, 2 ; mechanical drawing, 2 ; kindergarten, 2; Latin and English, 2; elocution and physical culture, 1 ; pediatrics, 1 .

The groups for which women qualify are therefore, in order of frequency: English, music, modern language, domestic science and home economics. In natural science and mathematics they do not often rise above the rank of instructor.

The high per cent. of women teachers west of the Mississippi may be explained by saying that the west is less conservative than the east; that there are more coeducational institutions in the west; that the western schools were founded after women began to compete for college positions, while the majority of eastern schools were founded before this time. Lack of ample funds may also at times have dictated the choice of cheaper service.

The number and per cent. of women in the various schools is given on page 56 .

C. H. HANDSCHIN

\section{SCIENTIFIC NOTES AND NEWS}

Mr. Arthur D. Littre, of Boston, was elected president of the American Chemical Society at the Washington meeting.

Profensor E. G. Conklin, of Princeton University, has been elected president of the American Society of Naturalists.

Professor Ross G. Harrison, of Yale University, was elected for the coming two years president of the American Association of Anatomists at the recent Princeton meeting.

Dr. S. J. MeLtzer, of the Rockefeller Institute for Medical Research, has been reelected president of the American Physiological Society.

The Academy of Natural Sciences of Philadelphia has awarded the Hayden Medal in gold for distinguished work in geology to Professor John C. Branner, of Leland Stanford Jr. University.

President Taft has nominated Dr. Rupert Blue, of South Carolina, as surgeon general of the public health and marine hospital service, succeeding the late Dr. Walter Wyman. President Taft gave notice that hereafter the term of service of the surgeon general of the public health service shall be limited to four years.

M. HenRI Bergson, professor of philosophy at the Collège de France, has been appointed visiting French professor of Columbia University for the year 1913. M. Bergson has also been appointed Gifford lecturer at Edinburgh.

The organ of the Japan Peace Society gives an account of the visit. of Dr. David Starr Jordan, president of Stanford University, in August, September and October, of last year, undertaken under the auspices of the Japan and American Peace Societies. Dr. Jordan gave a large number of addresses, mainly on peace and arbitration, at Tokyo, Yokohama, Sendai, Nagoya, Okayama and Osaka. At Tokyo between September 13 and 18, Dr. Jordan gave as many as ten addresses, not including after-dinner speeches.

DR. W. A. Cannon, of the Desert Laboratory, is acting director of the Department of Botanical Research of the Carnegie Institution during the absence of Dr. D. T. MacDougal, who is traveling and studying desert conditions in Upper Egypt and portions of the Soudan.

Mr. Mrron L. Fuller, for many years a geologist on the United States Geological Survey and chief of the Eastern Section of the Division of Hydrology from 1903-07, has formed an association with Mr. Frederick G. Clapp, also formerly of the Geological Survey, to act as consulting experts in all branches of geological engineering, especially in water supplies, bridge and dam foundations, ore deposits, oil and gas.

The Strand Magazine has obtained a vote to determine the ten greatest men now living. The speaker of the house of commons drew up a list of eighteen men and other distinguished men voted for names by reduction and substitution. The final list in the order of the number of votes was: Edison, Kipling, Roosevelt, Marconi, Lister, Chamberlain, Roberts, William II., Metchnikoff. 